\title{
First report of Artystone trysibia (Isopoda: Cymothoidae) in Caquetaia spectabilis (Cichliformes: Cichlidae)
}

\author{
Primeiro relato de Artystone trysibia (Isopoda: Cymothoidae) em \\ Caquetaia spectabilis (Cichliformes: Cichlidae) \\ Marcos Sidney Brito Oliveira ${ }^{1 *}$ (D); Pedro Hugo Esteves-Silva ${ }^{2}$; Marcelo Costa Andrade ${ }^{3}$ (D); Marcos Tavares-Dias ${ }^{1,4}$ (D) \\ ${ }^{1}$ Programa de Pós-graduação em Biodiversidade Tropical - PPGBIO, Universidade Federal do Amapá - UNIFAP, Macapá, AP, Brasil \\ ${ }^{2}$ Universidade Federal do Amapá - UNIFAP, Macapá, AP, Brasil \\ ${ }^{3}$ Laboratório de Ictiologia do Grupo de Ecologia Aquática, Universidade Federal do Pará - UFPA, Belém, PA, Brasil \\ ${ }^{4}$ Empresa Brasileira de Pesquisa Agropecuária - Embrapa Amapá, Macapá, AP, Brasil
}

Received February 5, 2019

Accepted April 11, 2019

\begin{abstract}
The present study provides the first record of an isopod parasite (Artystone trysibia) on Caquetaia spectabilis, a cichlid from the eastern Amazon collected in the State of Amapá, northern Brazil. In May 2018, specimens of C. spectabilis were collected in the lower Jari River, and $33.3 \%$ were parasitized by A. trysibia on the tegument tissue between pelvic fins. No hemorrhage or injury signals were observed in the tegument of the host. This study also expanded the distribution of $A$. trysibia to the eastern Amazon.
\end{abstract}

Keywords: Freshwater fish, isopod, Jari river, parasitism, tegmental hole.

\section{Resumo}

O presente estudo fornece o primeiro registro de um isópode parasito (Artystone trysibia) em Caquetaia spectabilis, um ciclídeo da Amazônia coletado no estado do Amapá, norte do Brasil. Em maio de 2018, espécimes de C. spectabilis foram coletados no baixo Rio Jari e 33,3\% estavam parasitados por $A$. trysibia dentro do orifício tegumentar localizado na regiâo ventral, entre as nadadeiras pélvicas de $C$. spectabilis. Nenhuma hemorragia ou lesôes foram observadas no tegumento dos hospedeiros. Este estudo amplia a distribuiçáo de A. trysibia para a Amazônia oriental.

Palavras-chave: Peixe de água doce, isópode, Rio Jari, parasitismo, orifício tegumentar.

Crustaceans of the family Cymothoidae Leach, 1818 are obligatory parasite isopods with direct life cycle and are found parasitizing both marine and freshwater fish (TAVARES-DIAS et al., 2015; OLIVEIRA et al., 2017a). These parasites can be found over the tegument, abdominal cavity, gills or in the buccopharyngeal area of the host, but this may vary according to the parasite species or the host species (SMIT et al., 2014; TAVARES-DIAS et al., 2015). However, isopods of the genera Artystone Schioedte, 1866 and Riggia Szidat, 1948 are tegument punchers of hosts (HUIZINGA, 1972; THATCHER, 2006; ODA et al., 2015).

The genus Artystone is composed of three species, all originally described parasitizing South American fish, i.e., Artystone bolivianensis Thatcher \& Schindler, 1999; Artystone minima Thatcher \& Carvalho, 1988 and Artystone trysibia Schioedte, 1866. These species of isopds are recognized by their high pathogenicity, since they penetrate in the host tegument to feed and to live (HUIZINGA, 1972; THATCHER, 2006). Records of the A. trysibia, a cymothoid

${ }^{*}$ Corresponding author: Marcos Sidney Brito Oliveira. Universidade Federal do Amapá - UNIFAP, Rodovia Juscelino Kubitschek, Km 2, Jardim Marco Zero, CEP 68903-419, Macapá, AP, Brasil. e-mail: marcosidney2012@hotmail.com originally described of a single female specimen collected in the Plata River (Argentina), are more frequent in Cichliformes fish species, but there are also reports of infestation in siluriforms fish species (JUNOY, 2016). This study makes the first record of A. trysibia parasitizing Caquetaia spectabilis Steindachner, 1875, a cichlid from the Amazon River basin, in Brazil.

Specimens of C. spectabilis were collected in May 2018 in the lower Jari River (1'9'19.3"S; 51 $59^{\prime} 9.3$ "W), near to the Jarilândia village, Municipality of Laranjal do Jari, in the State of Amapá, northern Brazil (Figure 1). Fish collected using gillnets ( $25 \mathrm{~m}$ long, 1.5 deep, $30 \mathrm{~mm}$ between knots) were measured for total length $(\mathrm{cm})$ and weighed $(\mathrm{g})$. Parasitized fish specimens were euthanized in clove oil solution (10\%), while the non-parasitized fish were returned to the river. Parasites found were maintained in ethanol solution (70\%) during $24 \mathrm{~h}$, and then preserved in alcohol (70\%) and glycerin (10\%), for analysis. Host and parasite were identified at the higher taxonomic level according to specific literature (THATCHER, 2006; JUNOY, 2016; QUEIROZ et al., 2013). Specimen of $A$. trysibia was measured on length and width, and dissected in order to get an accurate comparison of morphological 


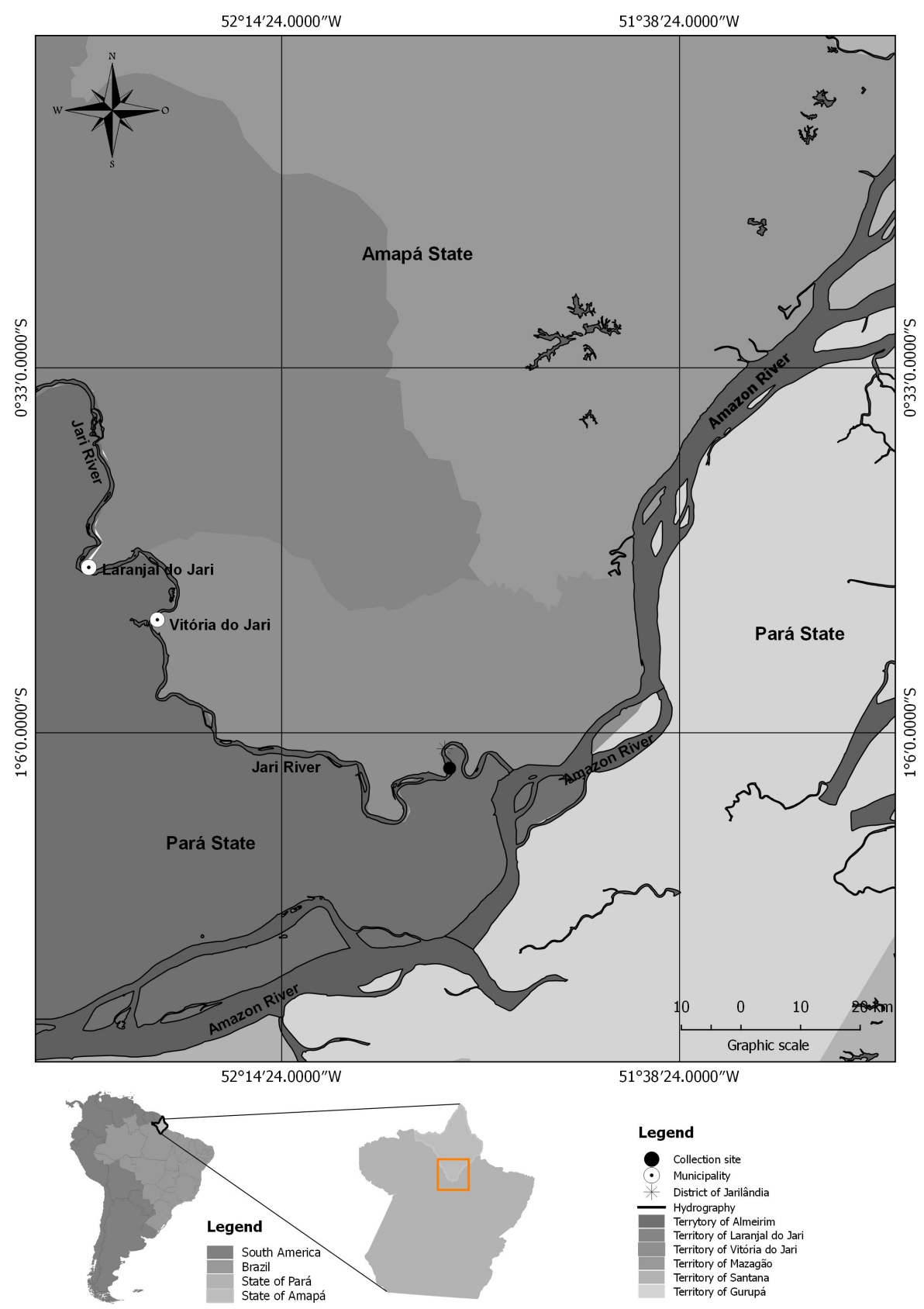

Figure 1. Site of study in the lower Jari River basin, between states of Amapá and Pará, in eastern Amazon, northern Brazil.

features. Mouthparts and appendages were carefully dissected for identification (THATCHER, 2006; JUNOY, 2016).

Three specimens of C. spectabilis, measuring $18.6 \pm 0.8 \mathrm{~cm}$ and $251.7 \pm 28.4 \mathrm{~g}$ (Figure $2 \mathrm{~A}-\mathrm{B}$ ) were collected, from those only one specimen was parasitized $(33.3 \%)$ by one specimen of A. trysibia (Figure 2C-G) found inside the tegument between the pelvic fins of the host (Figure 2B). The tegument damage showed a hole about $5 \mathrm{~mm}$ diameter and $25 \mathrm{~mm}$ deep forming a capsule (Figure 2B). No hemorrhage or internal organ injuries were detected macroscopically in the host.

For the Jari River basin, left-bank tributary of the lower Amazon River has been a total of 11 species of crustaceans parasitizing fish are known (see OLIVEIRA et al., 2017a, b;
GONÇALVES et al., 2018). However, this is the first record of A. trysibia for fish of this basin.

Species of Artystone are known for perforating the tegument of hosts (HUIZINGA, 1972; THATCHER \& SCHINDLER, 1999; JUNOY, 2016). This perforation causes hemorrhages by mechanical mutilation, in addition to necrosis and might cause organ injuries such as the eye loss (HUIZINGA, 1972). However, the penetration of $A$. trysibia in the tegument of C. spectabilis did not cause hemorrhage or injury signals in host of this study.

The present study contributes with: (i) distribution expansion of A. trysibia to the Jari River basin, in eastern Amazon and (ii) the first report of the occurrence of $A$. trysibia in C. spectabilis. 

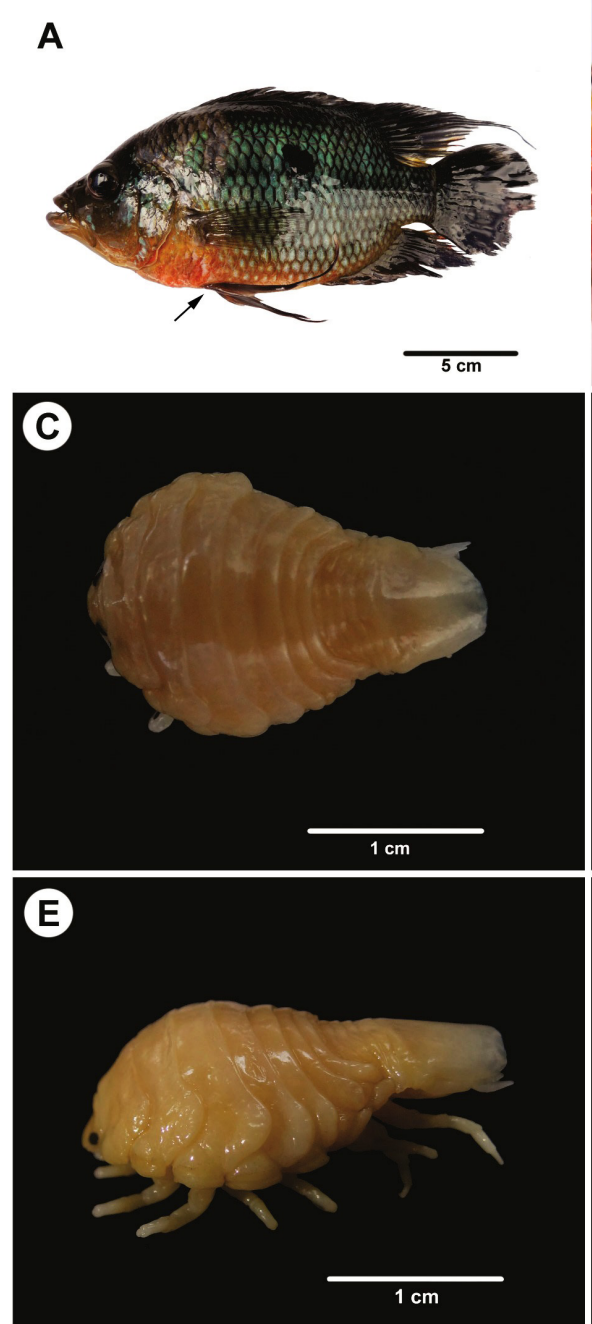

B
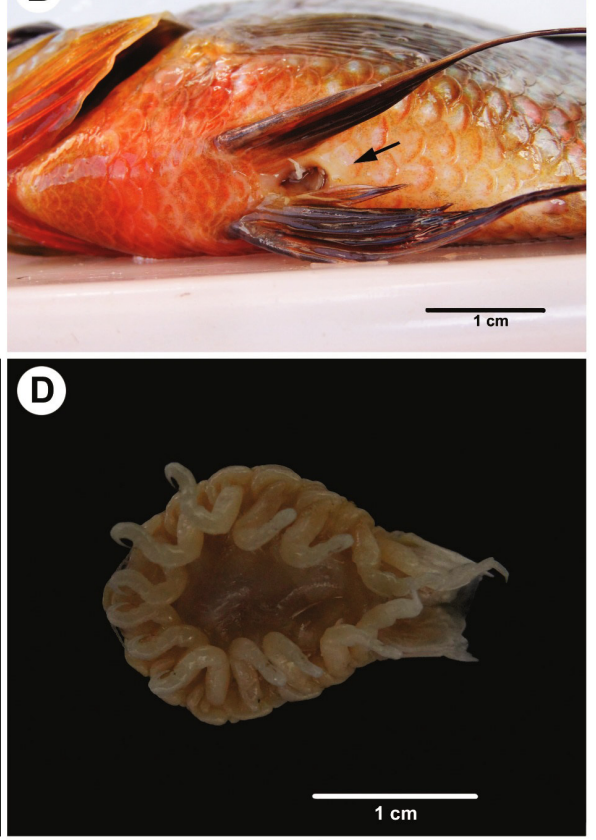

F

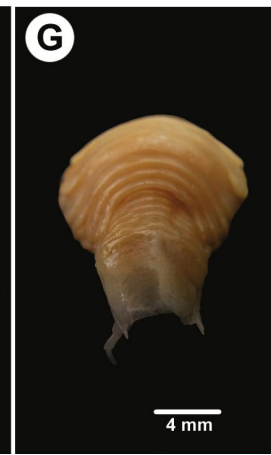

Figure 2. Caquetaia spectabilis from the eastern Amazon, in Brazil (A). Tegumentar orifice between pelvic fins area of Caquetaia spectabilis caused by Artystone trysibia (B). Artystone trysibia in views dorsal (C), ventral (D), lateral (E), frontal (F) and back (G).

\section{Acknowledgements}

We would like to thank for research grant from the Conselho Nacional de Desenvolvimento Científico e Tecnológico (CNPq) (\# 303013/2015-0) for Marcos Tavares-Dias and to the Coordenação de Aperfeiçoamento de Pessoal de Nível Superior (CAPES) for granting the Ph.D. Scholarship Grant for Marcos S.B. Oliveira.

\section{References}

Gonçalves BB, Oliveira MSB, Borges WF, Santos GG, Tavares-Dias M. Diversity of metazoan parasites in Colossoma macropomum (Serrasalmidae) from the lower Jari River, a tributary of the Amazonas River in Brazil. Acta Amazon 2018; 48(3): 211-216. http://dx.doi.org/10.1590/18094392201704371.

Huizinga HW. Pathobiology of Artystone trysibia Schioedte (Isopoda: Cymothoidae), an endoparasitic isopod of South American fresh water fishes. JWildl Dis 1972; 8(3): 225-232. http://dx.doi.org/10.7589/00903558-8.3.225. PMid:5049112.

Junoy J. Parasitism of the isopod Artystone trysibia in the fish Chaetostoma dermorhynchum from the Tena River (Amazonian region, Ecuador). Acta Trop 2016; 153: 36-45. http://dx.doi.org/10.1016/j.actatropica.2015.10.006. PMid:26466983.

Oda FH, Graça RJ, Tencatt LFC, Tavares LER, Froehlich O, Takemoto RM. The poorly known Riggia acuticaudata (Crustacea: Isopoda) parasitizing Ancistrus sp. (Siluriformes: Loricariidae) from the Paraguay River basin, Brazil, with comments on its reproductive biology. Comp Parasitol 2015; 82(1): 25-28. http://dx.doi.org/10.1654/4738.1.

Oliveira MSB, Corrêa LL, Ferreira DO, Neves LR, Tavares-Dias M. Records of new localities and hosts for crustacean parasites in fish from the eastern Amazon in northern Brazil. J Parasit Dis 2017a; 41(2): 565570. http://dx.doi.org/10.1007/s12639-016-0852-8. PMid:28615880.

Oliveira MSB, Gonçalves RA, Ferreira DO, Pinheiro DA, Neves LR, Dias MKR, et al. Metazoan parasite communities of wild Leporinus friderici (Characiformes: Anostomidae) from Amazon River system in Brazil. 
Stud Neotrop Fauna Environ 2017b; 52(2): 146-156. http://dx.doi.org/ 10.1080/01650521.2017.1312776.

Queiroz LJ, Torrente-Vilara G, Ohara WM, Pires THS, Zuano J, Doria CR. Peixes do Rio Madeira. 3. ed. São Paulo: Dialeto Latin American Documentary; 2013.

Smit NJ, Bruce NL, Hadfield KA. Global diversity of fish parasitic isopod crustaceans of the family Cymothoidae. Int J Parasitol Parasites Wildl 2014; 3(2): 188-197. http://dx.doi.org/10.1016/j.ijppaw.2014.03.004. PMid:25180163.
Tavares-Dias M, Dias-Júnior MB, Florentino AC, Silva LM, Cunha AC. Distribution pattern of crustacean ectoparasites of freshwater fish from Brazil. Rev Bras Parasitol Vet 2015; 24(2): 136-147. http://dx.doi. org/10.1590/S1984-29612015036. PMid:26154954.

Thatcher VE, Schindler I. Artystone bolivianensis n. sp. (Isopoda, Cymothoidae) from a loricariid catfish of the Bolivian Amazon. Amazoniana 1999; 15(3-4): 183-191.

Thatcher VE. Amazon fish parasites. 2th ed. Moscow: Sofia-Pensoft Publishers; 2006. 